\section{On the organic combination of public ownership and market economy}

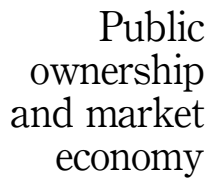

67

\author{
Yu Zhang \\ School of Economics, Renmin University of China, Beijing, China
}

\begin{abstract}
Purpose - Since the implementation of reform and opening up, China has made remarkable achievement in terms of economic reform and development. China's path, as well as its experience, has simultaneously gained worldwide concerns. Developing the market economy against the backdrop of socialism brings conclusions from China's achievement, deepens knowledge of China's pathway and builds a socialist political economy with Chinese characteristics. That is the way to realise a basic socialist system, especially with regards to the organic integration of public ownership and market economy. This combination determines the future of socialism with Chinese characteristics and the success or failure of economic restructuring. Therefore, it requires consideration and in-depth study. The paper aims to discuss these issues.

Design/methodology/approach - The goal of economic restructuring is to establish and develop the socialist market economy. Its main content can be summarised in two parts. The first is the relationship between plan and market or government and market. The second is compatibility or combination of public ownership and market economy. The former is one of the superficial problems, relevant to resource allocation method or economic operation mechanism. The latter stems from deep-rooted problems, represented by ownership or the underlying economic system. These two work together to form the organic integrity of socialist market economy where both similarities and contrasts coexist.

Findings - The shared ideal of socialism with Chinese characteristics and the lofty goals of communism will then become empty words. In this sense we can say that, whether we can realise the unity and opposition between public ownership and market economy and better integrate advantages of socialist system with strengths of market economy, will to a large extent determine the future and destiny of the socialist market economy.

Originality/value - As previously mentioned, the relationship between plan and market or government and market are part of resource allocation methods or economic operation mechanism. Compatibility and combination, however, with public ownership and market economy are part of an ownership or basic economic system. Science reveals the nature and developmental law of the socialist market economy. An in-depth study must be conducted on the relationship between public ownership and market economy.
\end{abstract}

Keywords Socialism, Public ownership, Market economy

Paper type Research paper

Since the implementation of reform and opening up, China has made remarkable achievement in terms of economic reform and development. China's path, as well as its experience, has simultaneously gained worldwide concerns. Developing the market economy against the backdrop of socialism brings conclusions from China's achievement, deepens knowledge of China's pathway and builds a socialist political economy with Chinese characteristics (SPECC). That is the way to realise a basic socialist system, especially with regards to the organic integration of public ownership and market economy. This combination determines the future of socialism with Chinese characteristics and the success or failure of economic restructuring. Therefore, it requires consideration and in-depth study.

\section{JEL Classification - P26, P23}

(C) Economic Research Journal. Published in China Political Economy. Published by Emerald Publishing Limited. This article is published under the Creative Commons Attribution (CC BY 4.0) licence. Anyone may reproduce, distribute, translate and create derivative works of this article (for both commercial and non-commercial purposes), subject to full attribution to the original publication and authors. The full terms of this licence may be seen at http://creativecommons.org/licences/by/4.0/legalcode. Originally published in Simplified Chinese in Economic Research Journal.
Received 31 July 2018 Accepted 31 July 2018 


\section{$\mathrm{CPE}$} 1,1

\section{Two principal lines of socialist market economy development}

The goal of economic restructuring is to establish and develop the socialist market economy. Its main content can be summarised in two parts. The first is the relationship between plan and market or government and market. The second is compatibility or combination of public ownership and market economy. The former is one of the superficial problems, relevant to resource allocation method or economic operation mechanism. The latter stems from deep-rooted problems, represented by ownership or the underlying economic system. These two work together to form the organic integrity of socialist market economy where both similarities and contrasts coexist.

Logic is inconsistent with history. The development of the socialist market economy centers on the above mentioned two parts and two principal lines in terms of theory and practice. It evolves from the exterior to the interior and from shallow to deep. Market socialism theory, as summarised by Roemer et al., has undergone five stages of development. The first stage is that socialist economy calculations must resort to the symbols of value rather than a physical unit. The second stage is that appropriate equivalent prices should be obtained through solving complicated equations. The third stage introduces the market and addresses economic imbalances through competition. The fourth stage shows various market-based theories and practices in socialist countries. The fifth stage emerged after the reform failure in the Soviet Union as well as Eastern Europe. The core concept is to seek enterprise institution unifying equity and efficiency (Roemer, 1994). The first four stages for the progress of market socialism theory focus on the relationship between plan and market. From 1960s to 1980s, many such reform theories have been raised by economists in Eastern Europe, including Lange model, Bruce's decentralised model, Ota Sik's free market model coordinated by macro income plan and Kornai's free market model under indirect macro control. That being said, as theory and practice progress, scholars come to realise that little attention paid to this relationship is far from enough for constructing the entire market economy. Whether public owned enterprises are able to and how they adapt to market mechanism are the crucial points, namely the combination between public ownership and market economy. Kornai et al. found that some assumptions could be just fantasies if the perfect competition market-based reform plans failed to deliberate on whether a traditional state-owned system could accommodate them or not. One such example is Oskar Lange's famous theory of stimulated market for a planned economy. It assumes that socialist entrepreneurs virtually behave the same as their private counterparts, but its basis is not fully explained. Thus the assumption ends up with a deficiency in the microeconomic base (Kornai, 1987). As to this problem, Ota Sik et al. proposed neutralised capital. This theory envisages that labourers, as owners of collective capital in public enterprises, engage in business management through democratic autonomy and share profits thereof. In this way, the contradiction existing between labour and capital can be overcome, and economy can embrace democracy and humanity (Sik, 1989a, b). Bruce, however, went in the opposite direction. He put forward socialisation of production materials. He believed that socialist ownership should be social ownership rather than state ownership. This features two basic standards. One goes that the means of production must be used to satisfy social benefits. The other is that the society must dominate its means of production. Of these, the second standard plays a decisive role, whose essence is political democratisation (Bruse, 1989). In short, scholars in the Soviet Union and Eastern Europe delved into the effect of market mechanisms on a socialist economy. They also deliberated on a combination of public ownership and market economy and achieved great success.

In China, exploration of the role of market mechanism started as early as when a socialist system was established. There were two significant discussions from 1956 to 1957 and from 1958 to 1959, respectively. After the reform and opening up, researchers made some breakthroughs on this problem. Theory continued to progress, and recognition kept deepening. The Third Plenary Session of the 11th Central Committee of the Communist Party of China 
$(\mathrm{CPC})$ stressed on law of value; the 12th National Congress of the CPC proposed the leading role of planned economy supplemented by market regulation; the Third Plenary Session of the Twelfth Central Committee put forward a planned commodity economy; the 13th National Congress raised a new economic operation mechanism, which, on the whole, affirms that the state regulates market while the market guides enterprises; the economic system and operation mechanism proposed post the Fourth Plenary Session of the Thirteenth Central Committee features a combination of planned economy and market regulation to accommodate the planned commodity economy. At the same time, another principal line for a socialist market economy, namely the combination of public ownership, commodity economy and the market economy, was put forward. Especially when the reform of state-owned enterprises (SOEs) became pivotal in economic restructuring, the system, mechanism and realisation form of public ownership have all been taken more seriously. The Third Plenary Session of the 12th Central Committee of the $\mathrm{CPC}$ has put forward that reinforcing the vitality of enterprises, in particular large and medium enterprises, is pivotal in economic restructuring with a city as its priority. Enterprises must become independent economic entities and socialist commodity manufacturers and operators responsible for their own management as well as profits and losses. Report at the 13th National Congress pointed out that enterprises owned by the whole people must be invigorated based on separation of ownership and management right, establishing a basic framework for a planned commodity economy with a focus on transforming enterprise operation mechanism.

The report at the 14th National Congress of the $\mathrm{CPC}$ specified the reform goal of the socialist market economy, enabling a historic leap in knowledge on the socialist market economy. The report pointed out that our objective in economic reform was a socialist market economy, in which nature was also summarised in an aspect of a primary system and resource allocation by the report. With regards to the fundamental system, the socialist market economy is combined with a basic socialist system. In terms of resource allocation methods, the socialist market economy system we aim to establish is to enable the market to play a fundamental role in allocating resources under the socialist macro-control. At this point, two aspects and two principal lines of a socialist market economy, namely the relationship between plan and market together with a combination of public ownership and the market economy have all been determined as essential characteristics of the socialist market economy. The Fourth Plenary Session of the 15th National Congress of the CPC specified that reforming SOEs is pivotal in the reform of the entire economic system. To establish and improve the socialist market economy as well as combine public ownership and market economy, the most important point is to bring into being the administrative system and management mechanism for SOEs to adapt to a market economy.

Since the 18th National Congress of the CPC, a new round of reforms aiming at improving the socialist market economy system have been comprehensively launched. The two aspects as well as the principal lines remain very clear. On the one hand, the Party Central Committee pointed out that the core of the economic restructuring is to handle the relationship between government and market, enable the market to play a decisive role in resource allocation and give full play to the government. On the other hand, the Committee emphasised that the underlying economic system of keeping public ownership as the mainstay and allowing diverse forms of ownership to develop side by side serve as an essential pillar for the socialist system with Chinese characteristics and the foundation for the socialist market economy. President $\mathrm{Xi}$ Jinping observed that we must remain committed to the direction in reforming the socialist market economy, adhere to dialectics and the doctrine that everything has two aspects, and foster and enhance the combination of basic socialist system and market economy (Jinping, 2015). The above remarks by President Xi fully demonstrate nature of dialectical relationship between two aspects and two principal lines of a socialist market economy.

However, it must be noted that the status and role of the two aspects are different. As previously mentioned, the relationship between plan and market or government and market are part of resource allocation methods or economic operation mechanism. 
$\mathrm{CPE}$ 1,1

Compatibility and combination, however, with public ownership and market economy are part of an ownership or basic economic system. Science reveals the nature and developmental law of the socialist market economy. An in-depth study must be conducted on the relationship between public ownership and market economy.

\section{Deepening the knowledge on the relationship between public ownership and market economy}

At present, what is the particular significance in deepening research into the relationship between public ownership and market economy?

First of all, it is required for adhering to and improving the socialist market economy system. Theoretical logic and practical experience both certify that the combination of public ownership and market economy play a key role in this regard. First, public ownership of the means of production is the basis of the socialist economic system. Our constitution specifies that the building blocks for a socialist economic system of the People's Republic of China are the socialist public ownership of the means of production, namely ownership by the whole people and collective ownership by the workers. In this sense, the socialist market economy is by no means possible without the combination of public ownership and the market economy. Second, the primary stage of socialism adopts public ownership as the mainstay while allowing diverse forms of ownership to develop side by side. There are commodity exchanges of various natures, such as exchange among private ownership, public ownership as well as the exchange between private and public ownership. Whether the combination between public ownership, a mainstay of a basic economic system, and a market economy is possible and how it happens determines the nature, characteristics and prospects of a socialist market economy to a large extent. Third, there is significant progress made through economic restructuring, the purpose of which, however, remains unfulfilled. A lot of contradictions and problems still exist. On the one hand, the regulatory role of the market mechanism is not in full use. What is worse, the market system is far from sound and factors of production fail to circulate smoothly. Equally, superiorities of labour-based distribution and planned development in public economy are not sufficiently demonstrated. Problems like large income gaps, the absence of master consciousness, overcapacity and serious corruption boil down to an immature and unstable combination of public ownership and market economy.

Second, further research is required to understand China's practical experience. The Political Bureau of the Central Committee of the $\mathrm{CPC}$ organised a collective learning on the fundamental principles and methodologies of Marxist Political Economy on 23 November 2015. President Xi Jinping made particular note that we must reveal new features and rules and refine the achievements of economic development and practice based on our national realities. In addition, we must turn experience from practice into systematic doctrines and keep exploring new boundaries of Marxist political economics in contemporary China. So, what is the most fundamental feature of China's practical experiences? This is an organic combination of the basic socialist system and the market economy, a combination of public ownership and market economy in particular. This combination, for one thing, allows market mechanism's sensitivity, incentive effectiveness, and flexible control, which enhances economic vitality; additionally, it must draw on the strengths from the socialist public ownership economy, such as putting the people first, overall consideration, independence as well as co-construction and sharing. Moreover, it must overcome blindness, spontaneity, hysteresis, financial crisis and income disparity in a capitalist market economy. On the one hand, it must commit to public ownership of the socialist economic system, distribution according to labour, regulation through planning, shared prosperity, comprehensive development and other basic principles. On the other hand, it must accommodate to the requirements of the market economic basics, develop the economy with different types of ownership and various allocation methods, allow the 
existence of exploitation, expand the role of spontaneous forces, strengthen personal interests and encourage free competition. How to enable organic combination of these two factors with mutual contradiction, transformation and restriction? This is a core issue in China's economic system reform. Coexistence, struggle of the two conflicting aspects and their integration in the new category belong to the dialectical movement (Engels and Marx, 2012a). The socialist market economy is a vivid reflection of this movement. Theoretically, the combination summarises successful experiences of the socialist market economy, surpassing doctrines of a capitalist market economy building upon private ownership. It is of great significance to the scientific socialism's development and human progress.

Third, further research is required by a SPECC. Currently, theorists are unclear or even confused about the relationship between public ownership and the market economy. After more than 30 years' in-depth reform, many opinions regarding economic system restructuring go backward, setting public ownership against the market economy. This is an unforeseen phenomenon. For instance, some believe that the SOEs should withdraw from competition or profitable sections. Instead, they can specialise in public products that are unappealing or inaccessible to private enterprises. Some consider that the large scale and rapid development of SOEs may seize and occupy private enterprises' development space, making private enterprises fall behind. There is also the opinion that leaders in SOEs cannot be defined as entrepreneurs. In this sense, their payroll is based on the standards set by government officials rather than the market standards. Others, however, object to public ownership set against market economy with reform and develop public ownership under a market economy. They assert that there is no contradiction between public ownership and the market economy. Moreover, the combination of the two in their opinion is well-reasoned with no need to be verified.

The above two contradictory viewpoints share one common premise, namely studying the combination of public ownership and market economy is no longer important. The difference is the former view advocates that developing the so-called true market economy can only be accomplished by full privatisation. It denies the socialist economic system radically. The latter view regards the market economy as neutral with no obsession for socialism or capitalism. Moreover, the public ownership economy should fully adapt to the market economy. This view seems reasonable but is confronted with numerous unresolved problems. For example, why is there a distinction between the socialist market economy and the capitalist market economy since the market economy is neutral? As SOEs are not exclusive leaders under public ownership, how can they make possible independent management and assume sole responsibility for their profits or losses? How can the job market or labour market come into being when labourers are the owners of the means of production? Competition leads to polarisation. How can it be compatible with the nature of shared socialist prosperity? If profit maximisation is the only aim that enterprises pursue, how can the people's material and cultural needs be met or the socialist objective of production thrive? All these problems can come down to one fundamental issue, which has been specified in Lange's "Theory of Socialist Economy", published in 1938. "If the rules for allocating resources to implement competition are the same as those for a rationally guided socialist economy, what is the role of socialism? If the same result can be achieved within the existing system, why should the entire economic system be changed if it is forced to keep its competition standards?" (Lange, 1981). There exists one paradox. If public ownership integrates with the market economy, the meaning of its existence will be lost. If the public ownership is set fully against market economy, the socialist market economy will lose its base for existing. How to resolve this paradox? Problems arise with their solutions. That is true of China's socialist market economy, which arise and develop in the process of problem-solving. Public ownership and market economy, as a consequence, undergo a historic transformation from opposition to unification. 


\section{$\mathrm{CPE}$} 1,1

\section{Opposition and unification of public ownership and market economy}

To understand the relationship between public ownership and market economy, we must return to the causes and features of commodity relation existence in a socialist public ownership economy. Once society owns means of production, commodity production will be removed. This is a classic theory voiced by Marx and Engels. In Critique of the Gotha Programme, however, Marx's perception in this regard has evolved. He classified the communist society into the advanced and infantile stages and elaborated on the difference between the two. "In a higher phase of communist society, after the enslaving subordination of the individual to the division of labor, and therewith also the antithesis between mental and physical labor, has vanished; after labor has become not only a means of life but life's prime want; after the productive forces have also increased with the all-round development of the individual, and all the springs of co-operative wealth flow more abundantly - only then can the narrow horizon of bourgeois right be crossed in its entirety and society inscribe on its banners: From each according to his ability, to each according to his needs" (Engels and Marx, 2012b).

Briefly speaking, public ownership of the socialist society is different from that of the advanced stage. The primary distinction is as below: the former builds on the division of labour, a particular organisation form of labour and technology; the latter, however, is based on the elimination of division of labour and the all-round development of individuals. Due to the existence of the division of labour, workers in a socialist society cannot be associated with means of production merely by the identity of co-owners in this regard, the same as the communist society. They must take labour as their means of living and integrate with public means of subsistence through the role of the labourer to get paid according to their work. The unique structure of socialist public ownership enables co-existence of commodification and noncommodification. That leads to certain contradictions and unification between public ownership and the market economy, which is key to understanding the relationship between the two.

Below is an analysis of the nature and characteristics of socialist public ownership and its relationship with the market economy in terms of property rights structure, distribution system and regulation methods.

\section{Dual attributes of socialist public ownership}

Commodity exchange is the exchange of ownership. "As a general rule, articles of utility become commodities, only because they are products of the labour of private individuals or groups of individuals who carry on their work independently of each other" (Marx, 2004a). "They must therefore, mutually recognise in each other the rights of private proprietors" (Marx, 2004b). Commodity exchange is based on independent private ownership. In this context, Marx and Engels asserted that once a society possesses the means of production, commodity production will be eliminated. In terms of public ownership's general attribute, the above inference is logical. Against the backdrop of public ownership, the means of production belongs to all labourers and all people are equal owners. No individual or group can gain special interest through ownership of the means of production. Satisfying the needs of the people has become the sole purpose of social production. In no way can this kind of production relation generate equivalent exchange relations. However, different conclusions can be drawn in terms of the socialist public ownership's particular structure. Regarding this socialist public ownership, although the means of production are jointly owned by members of the society, equal labour exchange is applied between the labourer and the enterprise. There exist distinct boundaries of interest. Therefore, socialist public ownership does not offer freely accessible public goods according to some scholars. On the contrary, it features clear exclusivity. First, social public property as a whole is exclusive to each individual member of the society. A single member of society is not automatically entitled to ownership and the derived rights because he is one of the public property owners. His possession and employment of the means of production are conditional, that is, the labour that meets the needs of society. Second, "The right of producers is proportional to the labour they supply.", 
"the same principle prevails as in the exchange of commodity equivalents: a given amount of labor in one form is exchanged for an equal amount of labor in another form" (Engels and Marx, 2012c). This principle as well as the producer's right to be paid according to his work is also one of the exclusive rights. Unlike private ownership of the means of production, this exclusivity is not exclusive to ownership in its essence, but stands for exclusivity of labour in exchange of an equivalent amount of product. This exclusivity in socialist public ownership requires an equal value-based exchange between different enterprises within public ownership. There must be relative independence in production and product allocation in publicly owned enterprises. In this way, national ownership and business operation rights can be separated. That is how a public asset management system can be established with clear property rights, strict protection, smooth circulation, as well as value maintenance and appreciation. This complex structure of public property rights is not only a particular requirement of socialist public ownership, but also conforms to the general development laws of property right system. In fact, the internal property rights structure after the establishment of ownership system is by no means invariable. All the main powers thereof can be centralised, separated, subdivided, restructured and implemented in various combinations according to the subject's interests, leading to various types of property allocation models (Xuangong, 1998). This also applies to socialist public ownership.

However, this kind of commercial property of public-owned enterprises is only regional, and it is fundamentally different from the overall goods exchange among private producers. In modern economic terms, the public ownership of means of production is a macro rather than a micro concept. The production of publicly owned enterprises features the direct need of the society. Although this society cannot be adjusted through direct planning as conceived by Marx, it is not entirely missing after the implementation of the socialist market economy system. Instead, it proves its existence with hard facts. First, public enterprise production cannot only commit to private interests but must also satisfy the common interests of the society. It cannot merely focus on the efficiency of enterprises in microcosmic aspect (profit maximisation), but must also undertake critical social responsibilities, such as protecting people's livelihood, safeguarding economic security, implementing macro-control and promoting independent innovation. Second, the management of publicly owned enterprises does not merely mean internal matters but features clear public qualities. As a representative of public ownership, the public asset management bureaus must be granted the right to make big decisions on corporate investment, distribution and personnel. The relevant stakeholders also have the right to monitor business operations so as to ensure that social interests are not taken over by corporate groups. Third, the economic surplus in the distribution of publicly owned enterprises does not belong to any individual or group. It is, in its essence, collectively owned public accumulation. Some of them are turned over in the form of profits and taxes, and some are left for the enterprises to expand and reproduce. The public nature of economic surplus is a concentrated expression of the production data in the distribution relationship.

In the process of integration of public ownership and market economy, a shareholding system is undoubtedly an effective form of realisation. Its role is so important that some people think that the corporate form of shareholding companies makes ownership completely useless. Therefore, demutualization in public-owned enterprises and establishment of corporate governance structure can create a capital market without capitalists. It enables the operation of public capital to be fully separated from the state regulation and control but completely based on the market economy. This kind of perception is reasonable and has been verified to some extent by success stories from SOE reforms. That being said, the viewpoint is one-sided as it only focusses on the public capital's commercial nature partially but ignores its direct sociality. This sociality determines that public capital operation cannot be built on spontaneous market transactions completely. This is because, in the property relations of public ownership, there are not only horizontal exchange of goods between enterprises but also vertically entrusted multilevel agent relations, which happen between the entire people and the state, the state and 
CPE 1,1

ownership representatives of state-owned capital as well as the representatives of business operations. These vertical agent relations are not equivalent to commodity exchange relations. For example, in terms of the relationship between all members of the society and the state-owned capital management agencies, it is a matter of political system design. In terms of the relationship between state-owned capital management agencies and business operators, it is a matter of ownership and operation right separation. These vertical agent relations require the establishment of a rational macro-control system and a public asset management system. In addition, government behaviours must be scientific and democratic. However, the market mechanism is incapable in this regard. It is a fact that although the socialist basic economic system with public ownership as mainstay has been established and become the guiding principle for China's economic reform and development, structural change in ownership under market economy depends on market mechanisms to a large extent. Various factors may exert an impact such as market competition, globalisation, and capital flow. In this context, if there is no effective macroeconomic regulation and protection, the basic socialist system with public ownership as its mainstay may well be deconstructed by spontaneous capitalist forces and become a kind of legislative fantasy. At that point, the socialist market economy will end in failure.

\section{Plan and market in socialist public ownership economy}

According to Marx and Engels's classic theory, socialist production is plan-based. Moreover, planning or adjustment is an essential feature of the socialist economy. Marx pointed out in Das Kapital: "[...] a community of free individuals, carrying on their work with the means of production in common, in which the labour-power of all the different individuals is consciously applied as the combined labour-power of the community" (Marx, 1975). In Anti-Duhring, Engels pointed out: "With the seizing of the means of production by society production of commodities is done away with, and, simultaneously, the mastery of the product over the producer. Anarchy in social production is replaced by systematic, definite organization", "It is the humanity's leap from the kingdom of necessity to the kingdom of freedom" (Engels and Marx, 2012d). Based on the above theories of classic writers as well as realities from that time, the initial economic system model came into being, as a highly centralised planned economic model. The highly centralised planned economic system has played a crucial role in consolidating the new socialist system and proceeding large-scale industrialisation. Its historical contribution cannot be denied. However, it turns out that the highly centralised system of planned economy tends to integrate government with enterprises and ignore the effects of commodity production and market forces, which seriously hampers the development of productivity. The shift from a highly centralised planned economic system to a dynamic socialist market economy is historically inevitable.

However, can we simply take this kind of transformation as market's victory over planning as well as spontaneity over self-consciousness? The answer is no. Planning and market are not the fundamental factors in distinguishing socialism and capitalism, but they are neither tools that have nothing to do with the social system. The nature, status, and role of planning and market under various social systems are different. A planned economy is not equal to socialism. However, planning is not an option for socialism, but one of the essential attributes of a publicly owned economy (Guoguang, 2010). This is because, in the public ownership system, all members of society are co-owners of means of production. The social production is to satisfy their common interests. However, if there is no unified social plan, economic entities that pursue their own interests will blindly compete in the market. This will not only lead to the failure in achieving the common interests of the society but may also degrade the socialist public ownership system to a group ownership, ending up being overwhelmed by the ocean of private ownership. The development of the publicly owned economy, therefore, cannot completely be built on the spontaneous market but must rely on 
the collective rationality or social plan as its own realisation form. Some may say that capitalist countries also have state intervention while some even have implemented economic plans. Thus, planning is not the essence of socialism. However, the intervention of the capitalist countries in the economy is based on private ownership and is always confronted with an insoluble contradiction: If the state's intervention is insufficient, there will be difficulty in dealing with unemployment, economic crisis and income gap in the capitalist market economy. If the intervention is excessive, the sacred doctrine of private ownership will be undermined, and the vitality of the capitalist economy will be impaired. The intertwining of market and government failures is an unavoidable consequence in the development of fundamental capitalist contradictions. Facts have repeatedly proven that genuinely effective planning and adjustment are impossible for a private ownership-based capitalist market economy. As Marx pointed out long ago, "There is no sense of existence from the beginning of production, which is the crux of bourgeois society". Consciousness-based regulation and supervision, as well as adjustment in the process of social production, is said to infringe upon the "originality" of the capitalist's property rights, freedom, and self-determination. Under public ownership, the link in all production is "the rules that are governed by their collective rationality enable the production process subject to their joint control" (Engels and Marx, 2012e). This collective control on socialist production serves as nature of the socialist economic planning. The state macro-control in the socialist market economy is based on this nature. This is essentially different from state intervention in the capitalist economy.

First, the primary basis for macro-control implemented by socialist countries is not in the so-called market failure, but public ownership of means of production as well as the planned and proportionate development law generated from this. Whether there exist so-called market failures or not, the state as the general representative of public ownership of production materials and public social interests must be able to regulate social reproduction process in accordance with the needs of the society and allocate social resources as long as the public ownership dominates. Second, the primary target of the macro-control in socialist countries is not to maintain short-term equilibrium of the total and create macro conditions for operation of the market mechanism, but to formulate and implement correct economic development strategies in light of the overall situation and long-term interests of economic and social development. Take into account the significant proportions in all aspects, promote sustainable social, economic development and satisfy the growing material and cultural needs of the people. Third, the means by which the socialist countries plan to regulate are not limited to the indirect demand management, namely fiscal and monetary policies, but also include many regulatory measures that are directly controlled and implemented by the state. These include formulating development plans, coordinating regional relations, creating strategic industry, supervising state-owned capital, investing in infrastructure, promoting technological innovation, as well as adjusting industrial structure and income distribution.

\section{Equal work exchange and exchange at equal values}

In socialist public ownership economy, personal consumer goods are distributed according to work. After various deductions, personal consumer goods are distributed in accordance with the labour completed by workers. Equal work exchange is applied. Marx believes that, "the same principle prevails as in the exchange of commodity equivalents: a given amount of labor in one form is exchanged for an equal amount of labor in another form" (Engels and Marx, 2012f). This assertion is significant. A simple deduction will reveal the revolutionary ideas in it. First of all, equal work exchange actually acquiesces that "unequal individual endowment, and thus productive capacity, as a natural privilege" (Engels and Marx, 2012b). That means that labour belongs to individuals. Second, this kind of equal labour-based exchange also requires social dimensions and standards. This transforms labour of different specific forms into general social labour and transforms the labour of different complexity 
$\mathrm{CPE}$ 1,1

and intensity into average social labour. This social scale is only abstract in terms of average social labour, which is similar to value of commodities. Third, abstract social general labour can be directly calculated within an enterprise. Other than market mechanisms, however, there may not be a better way at this moment to transform the complicated and unpredictable individual labour into general average social labour across the entire society. In this way, one kind of profound intrinsic link has occurred between the realisation of distribution according to work and the market economy.

The question is that, since Marx had already noted the commonality between equal labour exchanges and equivalent exchanges, why he still insisted that "within the co-operative society based on common ownership of the means of production, the producers do not exchange their products, just as little does the labor employed on the products appear here as the value of these products" (Engels and Marx, 2012f). In this regard, Marx's explanation is that the content and form have changed. In terms of form, the exchange of equivalents happens only on average, not in every single occasion; and in the equal exchange of labour in public ownership, individual labour no longer goes through a tortuous path. Instead, it exists as an integral part of total labour. In terms of content, commodity exchange based on private ownership feature all labour products. In public economy, no one can provide anything other than one's own labour. Also, none can be converted to personal property other than individual consumption information. In addition, general abstract work, as scale of equal labour exchange, is generally affected by subjective conditions of labourers rather than objective conditions such as quality of production materials, like the socially necessary labour that forms the value. In other words, labour-based distribution only recognises the difference of labour quality through income distribution but does not recognise the influence of the quality of material production. In this way can equality in labour and remuneration can be achieved (Jun, 1982). Therefore, principles of equal labour exchanges embodied in distribution according to work are not the same as equivalent exchanges in commodity exchange.

How can this contradiction between equal labour exchange and equivalent exchange be resolved? That is, how can we develop commodity currency relations as well as market economy, and at the same time make socialist distribution according to labour possible? In real life, the realisation of distribution according to work, first of all, must rely on the market mechanisms. On the one hand, links among enterprises are based on commodity exchanges. Exchanges tend to be carried out in accordance with amount of value determined by the necessary labour time in society. Enabling market mechanisms to play their role so that the economic benefits of enterprises will continue to increase competition. The economic benefits created and realised by enterprises are the basis for labour evaluation. On the other hand, the specific labour of different forms and the individual labour of different labourers are enabled to compare with each other. However, the allocation through market mechanism is just a precondition for distribution according to work rather than the end. The realisation of distribution based on work goes through at least three steps. First, apart from taxing enterprises as a public power, the state must also collect capital gains from SOEs as an owner. This income is not only the realisation of public capital ownership in economy, but also to some extent, eliminate the impact of means of production occupation differences on enterprise's distribution of income. It creates conditions for equality in work and remuneration. Second, in publicly owned enterprises, the relationship between accumulation and consumption ratios correlates with the interests of the state, the collective, and the individual. It serves as the integration point for state's macro-level decision-making and enterprise's micro-level decision-making. If there is no state adjustment on enterprises' income distribution, there may be problems such as wage erosion, accumulation of consumption, and collective interests impairing social interests. Third, the distribution of personal income in enterprises includes wages, bonuses, and benefits. This is the last link of distribution according to work, and this link is inseparable 
from state adjustment. State regulation mainly aims to regulate the proportion of income between a company's managers and workers internally, prevent excessive income disparities among managers and workers, and dissuade enterprise managers from seeking personal gains and undermining public profits.

Therefore, fair labour exchange is realised both in the market and outside the market. It depends not only on market regulation but also on national regulation. Only after entering the production process will everything be revealed, just as capital appreciation happens both in and outside of circulation.

\section{Labourer's master status and labour market}

The separation of means of production from the workforce, labourers becoming commodities, and capital employing labour and possessing surplus value created by workers are essential features of the capitalist production mode. In public ownership, the contradiction between labour and capital is eliminated, and the labourer is the co-owner of means of production, rather than the production factor that produces surplus-value for capital. This means the labour force loses its commercial nature. However, we cannot conclude that only planning and adjustment can therefore be deployed for labour in a public economy. As a matter of fact, in the socialist public ownership economy, there are both technical and institutional bases for the labour force to adopt a market-oriented approach. First, in the context of large-scale social production, the ever-changing technological and economic structure requires workers to make many transfers between different departments and enterprises so as to meet productivity requirements. Second, it aims to eliminate division of labour and realise people's all-round development judging from the general attributes of public ownership. Labourers are free to transfer from one department or area to another, which is an important condition for this purpose. Third, both enterprises and labourers are relatively independent economic entities with different economic interests judging from the special attributes of socialist public ownership. Therefore, they need to make two-way choices and free integration in accordance with their own interests. Formally speaking, this free combination between labourers and enterprises also stands for an equal contractual relationship. It, at the same time, features price modality of labour salary and must be regulated to some extent by the relationship between labour supply and demand.

However, in the public-owned economy, the labour force is not a commodity, nor can it be wholly deployed according to market-based principle when seeing through appearance to perceive essence. First of all, managers and labourers are equal in possession of means of production in the public-owned economy. The workers of enterprises have the right to manage production and business activities in a democratic manner, as well as elect and supervise managers of enterprises. A new relationship of cooperation, now featuring equality and mutual benefit has developed. Therefore, there is no employment relationship in its true sense. Second, labourers share the business results of enterprises based on the principle of distribution according to work in the public-owned economy. Their income depends mainly on their labour contribution and economic benefits of enterprises, instead of entirely on the supply and demand of labour force. Third, in the public-owned economy, once workers enter the enterprise and integrate with production materials, they will enjoy the rights and interests of co-owners of production materials and undertake the social responsibility of safeguarding common interests of the people. In addition, full-employment plays a much more critical role in public ownership economy from a macro point of view. In the capitalist economy, the relative surplus population, as the industrial reserve force of capitalist production, is an essential mechanism in regulating the reservoir of the labour market and guaranteeing capital control over labour. In the public-owned economy, the ownership status of labour force and the equal labour and equal pay are based on the direct combination of labourers and means of production as well as "distribution according to 
$\mathrm{CPE}$ 1,1

ability". Otherwise, the common possession of production materials will become empty words. In this sense, full-employment is one of essential requirements of the public ownership economy. In short, the commercialisation of labour force in the capitalist economy is based on opposition between capital and labour as well as subordination of labour to capital, while commodity form of labour in socialist public ownership economy is the realisation of the combination between labour force as owner of labour and means of production. It is a productive relationship of equal labour based on common possession of means of production. The essence of the relationship is to get rid of the labour's subordination to capital, enabling the people's free and comprehensive development.

\section{Market economy and common prosperity}

Whether public ownership and the market economy can be integrated and how it actually happens equates to whether the essence of socialism can be realised through a market economy. The essence can be understood from two aspects: one is ownership or the basic economic system, and the other is production purpose or value standard. In terms of ownership or basic economic system, the socialist system is based on the public ownership of production means. In terms of production purposes or value standards, the essence of socialism is to satisfy people's growing material and cultural needs and achieve common prosperity. Then, what is the relationship between essence of socialism and market economy? On the one hand, the realisation of the essence cannot be separated from market economy. Only through development of market economy can we make possible universal material transformation, comprehensive relationship, multi-faceted needs and overall capability system. That is how we can enable full source of wealth to emerge and lay down the material foundation for individual freedom as well as social common prosperity. On the other hand, the realisation of this essence cannot rely on the market economy, because market competition follows the "jungle law". Especially in the capitalist market economy, the general law of capital accumulation leads to the polarisation of wealth possession. One extreme is the accumulation and increase of wealth in the hands of a few, and the other is the relative poverty of the majority. The accompanying problems include confrontation between labour and capital, intensifying class conflicts, economic crisis of excessive production as well as capital concentration and monopoly. Confronted with serious shortcomings of market economy, the capitalist countries advocating freedom also have to turn to state interventionism, acknowledge responsibilities in regulating income distribution and establish social security and welfare systems. This is still the case in a capitalist society based on private ownership with labour hired by capital. How can socialism based on public ownership, satisfying people's needs and realizing common prosperity, be entirely dependent on the market economy? To make possible common prosperity, it is necessary to expand the intensity of income redistribution adjustments, including measures to improve the social security system, increase public expenditures and increase transfer payments. We must speed up the improvement of redistribution and adjustment mechanism that focus on taxation, social security and transfer payments. However, the realisation of common prosperity in socialist economy, different from capitalist countries depends not only on redistribution of national income but also on protection of initial distribution based on basic socialist system and distribution system. As Deng Xiaoping pointed out: "Polarization can be avoided as long as public ownership dominates our economy” (Xiaoping, 1993a). "Upholding socialism and implementing distribution according to work will not lead to big income gap" (Xiaoping, 1993b).

The analysis of several aspects above shows from different perspectives that socialist public ownership economy features both commercial and non-commercial nature. In this sense, an inevitable conclusion that the relationship between public ownership and market economy is "unity and opposition" can be drawn. This means that their organic combination must follow the laws of market economy and reflect the requirements of public ownership; it is necessary to give full play to the strengths of market economy while also demonstrating 
superiority of socialist system. This unity and opposition is exactly what the essence of the socialist market economy is. The socialist public ownership, characterised by division of labour and exchange of equal labour, naturally features commodity relations. From this perspective, there exists an inherent consistency between socialist public ownership and market economy. On the other hand, the purpose of establishing public ownership is to overcome basic contradiction between social production and capitalist private ownership, plan production according to needs of society, satisfy common interests of social members, and realise man's overall development and common prosperity. In this sense, socialist public ownership features direct sociality surpassing market economy. Both commercial and non-commercial aspects are the intrinsic properties of public ownership as well as essential requirements of socialist public ownership. The traditional socialist theory only captures the contradiction between public ownership and market economy, but ignores the compatibility between the two. This seriously hampers the development of commodity-currency relations together with the role of the market, and constrains the vitality of socialist economy. In the process of reform and opening up and developing the socialist market economy, some tend to merely see the compatibility of public ownership and market economy, while ignoring the contradictions and conflicts thereof. They intentionally or unintentionally weaken and dilute the particular goals and requirements of the socialist system. Only by profoundly grasping the inherent logic of the organic integration in unity and opposition can we truly grasp the essence of the socialist market economy.

\section{Enlightenment to deepen economic system reform in an all-round way}

The Third Plenary Session of the 18th CPC Central Committee unlocked a new stage of deepening reforms. A new round of reforms is emerging. Understanding the contradictory relationship between public ownership and the market economy has significant implications for the deepening reform of economic system and the accelerating enhancement of socialist market economic system.

\section{Acknowledging the direction in reforming the socialist market economy}

As mentioned above, the reform of the socialist market economy largely consists of two aspects: first, the relationship between planning and market or government and market in resource allocation; second, compatibility or integration of public ownership and market economy in the underlying system. These two aspects together adequately reflect the essence of socialist market economy, and then make the overall objective of reforming and developing the socialist system with Chinese characteristics possible. Judging from the former, the goal of comprehensively deepening reform of economic system is to enable the market to play a decisive role in resource allocation and better play the role of the government. Viewed through the latter, the goal is to improve the socialist system with Chinese characteristics and better demonstrate its superiority.

What is the major problem for deepening reforms of the economic system? The answer usually goes that the remnants or market-based reforms of the old planned economy are not thorough enough. Management from government in the micro economy is excessive while the market fails to give full play to its role. For instance, the scope of administrative examination and approval is too broad, the prices of some essential resources and production factors have not been settled, and the urban-rural system remains divided. Therefore, we must promote reform in related fields by focussing on the decisive role of market, drastically reducing the direct allocation of resources by government, accelerating improvement of the modern market system, and further enhancing the vitality of the market. However, these cover just part of the problems. Some problems, such as overcapacity, income gap, financial risks, environmental pollution, food and drug safety, and shortage of employment and social security, obviously cannot be attributed merely to 
$\mathrm{CPE}$ 1,1

remnants of the old planned economy or incomplete market reforms. These problems, to a large extent, are inherent disadvantages of market economy, inevitable even in the advanced capitalist market economy. It is unrealistic to resolve the defects inherent in market economy with a so-called thorough market approach. The fundamental way to overcome these drawbacks lies in improving the socialist system with Chinese characteristics and giving better play to the superiority of the socialist system. The most important thing is to uphold and perfect the underlying economic system featuring public ownership as the mainstay and joint development of multiple ownerships. We must adhere to improve the primary allocation system in which distribution according to work as the main body, and various distribution modes coexist. In doing so, the state macro-control in socialist countries plays its role while social fairness and justice can be ensured, realizing shared prosperity for all members of society.

\section{Acknowledging the objectives in developing socialist economy}

Social and economic development is a process of organic integration of productive relations and productivity. Socialist economic development includes two aspects: first, liberate and develop productive forces, boost labour productivity and create more social wealth; second, meet the growing material and cultural needs and promote man's all-round development. The former serves as means while the latter is the purpose. In this connection, the fundamental laws of the socialist economy can be fully reflected. That is, to continually increase and improve socialist production on a highly technical basis to maximally ensure the growing material and cultural needs in society. Deng Xiaoping pointed out that the essence of socialism is to liberate and develop productive forces, eliminate exploitation and polarisation, and finally achieve shared prosperity. This also reflects the requirements of these two areas.

Since its reform and opening up, China's social productive forces have undergone tremendous development, and people's living standards have continuously improved. However, at the same time, we are confronted with some deep problems at the institutional level. For example, some local governments and departments only focus on the pursuit of material wealth and GDP but ignore the development of education, medical care, and social security. When aggregate income increased substantially, the gap in wealth and income distribution also widened significantly. In order to maximise profit, some companies impair the legitimate rights and interests of workers, manufacture substandard and counterfeit products, destroy resources and the environment, and harm the interests of consumers. Cadre bureaucracy and corruption prevail. Officials seek private gains and isolate themselves from the masses. The existence and development of these problems violate the essence of the socialist system. Why are people-related problems fundamental? As Xi Jinping stressed, we must focus on people, which is the fundamental position of the Marxist political economy, we must adhere to the promotion of people's well-being and their all-round development, and steadily step in the direction of shared prosperity. More effective institutional arrangements must be made to grant all people a sense of gain and to advance steadily towards common prosperity in the process of co-construction and sharing (Jinping, 2015).

\section{Acknowledging the direction for reforming SOEs}

SOE reform determines our country's basic economic system. It is a matter of national security and the party's ruling foundation and must be well-accomplished. Understanding and embodying the nature of SOEs is the key to success of reforms. The nature of SOEs boils down to "ownership by and service for the entire people". The Third Plenary Session of the 18th CPC Central Committee emphasised that, "State-owned enterprises belong to the entire people and are an important force in advancing modernization and safeguarding common interests of people". Only by defining this fundamental nature can we profoundly understand why we must unwaveringly consolidate and develop the public-owned 
economy, expand and grow SOEs with integrity, and not take the road of privatisation to grasp the correct direction in reforming SOEs. Essentially, the purpose of deepening reform of SOEs is to shape more perfect systems and mechanisms, fully embody the fundamental attributes and internal requirements of SOEs, and give play to the superiority of the socialist system so as to better serve interests of the entire people.

SOEs also feature the same general attributes as other types of enterprises, such as independent property rights, independent management, as well as value-added and maintenance. Therefore, SOEs must become independent producers to expand in the market competition. SOEs must adhere to market-based direction, build a corporate governance structure that is coordinated and effective, establish effective incentive and restraint mechanisms to standardise business decisions, preserve and increase the value of assets, engage in fair competition, improve enterprise efficiency and enhance enterprise vitality.

However, this just considers one aspect. For SOEs, it is far from enough to demonstrate only general attributes of companies and general requirements for marketization. They must better reflect the nature and requirements of all citizens and services for the people. First, the income of state-owned capital belongs to all people. At this stage, it is necessary to increase the proportion of state-owned capital turned over to public finances, and more will be invested in protecting and improving people's livelihood. Second, state-owned capital investment and operation should serve the national strategic objectives, focussing on public services, developing important forward-looking strategic industries, protecting ecological environment, sustaining scientific-technical progress and safeguarding national security. Third, promote economic democracy, improve people's congresses at all levels, perfect supervision mechanism for state-owned capital management by relevant supervision agencies and all walks of life, and improve the mechanism for workers to engage in the democratic management of enterprises. Fourth, distribution according to work and common prosperity must be applied in income distribution of SOEs, so as to ensure fairness and justice and avoid polarisation. Fifth, fulfil social responsibilities, implement the party's principles and policies, and take into account the interests of the state, groups, individuals, and all aspects. With these five areas fulfilled, SOEs can give full play to their institutional superiority, better serve the people and gain their wholehearted support.

\section{Acknowledging the relationship between government and market}

The market economy is an economic system that regulates resource allocation through market mechanisms, namely, supply and demand as well as the role of price and competition. In the context of different social systems, however, the range and conditions under which market mechanisms function are not precisely the same. In a pure commodity economy, the role of the market mechanism is mainly confined to a limited range, and non-market factors such as blood tie, grade and power dominate economic life. In capitalist market economy, the market mechanism is not only reflected in commodity production and exchange, but also in allocation of capital, labour, and natural resources. It is not only embodied on the micro level, that is, market's adjustment on producers and consumer economic activities, but also reflected on the macro level, that is, the adjustment of all sectors of society and various economic relations. It is not only the case in economic field, but in all walks of life. In the final analysis, the market's decisive role comes down to the decisive role of capital. Capital thus becomes a "light of illumination" that governs the socio-economic, political, and cultural fields. The particular laws of capitalist economy have become the general law of the market economy such as surplus value, capital accumulation and equalisation of profits. The fundamental contradictions of capitalism and their manifestations have become increasingly intensified, such as class contradiction, economic crisis and income gap.

From the microeconomic point of view, both privately owned and publicly owned enterprises in a socialist market economy must pursue profit maximisation and accept the adjustment of market mechanisms. In other words, the market plays a decisive role in resource 
CPE 1,1

allocation. In terms of social development and macroeconomics, however, the purpose of product development or resource allocation is not profit maximisation, but the utmost satisfaction of people's material and cultural needs, realisation of all-round development and shared prosperity of society. The leading role is played by party leadership and national macro-control rather than the spontaneous market adjustment. In this context, deepening the reforms of the economic system and handling the relationship between government and the market must begin in two areas. On the one hand, reform in related fields must proceed with more respect for market laws and improved market vitality. Besides this, administration must be further simplified, and the market system further strengthened. On the other hand, we must promote reforms in related fields by giving full play to government's role and improving its efficiency. We must fulfil the responsibilities and roles of the government, strengthen planning and strategic guidance, maintain macroeconomic stability, enhance and optimise public services and safeguard fairness. We must guarantee fair competition, strengthen market supervision, maintain market order, boost sustainable development, promote shared prosperity, remedy market failures, enhance the country's economic governance capacity, utilise institutional advantages of the socialist market economy, and boost the economy to be more efficient, fairer, and more sustainable.

\section{Concluding remarks}

In the above analysis, we set aside the coexistence of diversified ownership, and conducted a detailed examination on the internal structure of socialist public ownership and its relationship with the market economy. It is crucial but incomplete for grasping the nature and laws of a socialist market economy. China will remain in the primary stage of socialism for an extended period. It will adopt an underlying economic system in which public ownership is the mainstay while allowing diverse forms of ownership to develop side by side. There are also various other forms in the public economy, such as the collective and cooperative economy. In addition to commodity relationships in public ownership economies, there are commodity relationships between public ownership and non-public ownership, and between non-public ownership and non-public ownership. These different types of relationships are intertwined to form a realistic socialist market economic system. Such a system can also find its theoretical origin in the classic literature for development of scientific socialism.

In Marx and Engels' classic theory, there are actually two socialist economic models at different stages of development. One is a mature and complete socialist model. It is characterised by the public ownership of means of production, distribution according to work, and planned economy. Class and state are eliminated, and there is no ownership system and commodity-currency relations other than public ownership. This is the first stage of communism. The Critique of the Gotha Programme is a representative work demonstrating this model. The other refers to the transitional period of socialist model. In this model, the state has already been placed in the hands of the proletariat. The state-owned economy controls key sectors of the national economy.

However, in agricultural production, the cooperative system is implemented. In addition, there is a significant amount of private ownership economy. Moreover, the market mechanism for commodity-currency relations has also played an essential role in retaining profits, interest and land rent. The ten measures proposed by the Communist Manifesto for transition to communism reflect the outline of this model. It is not difficult to see that Marx's description of the transitional economic model is entirely consistent with the current socialist market economy under implementation. The most important point is that there are both factors of socialist public ownership and capitalist private ownership. Moreover, they require mutual accommodation and shared development during a relatively extended historical period. Of course, there are contradictions and conflicts coexisting. This leads to a problem that is of vital importance to socialism, namely, who serves as the main body of the 
socialist market economy where economies of diversified ownership coexist? How can the socialist nature of market economy be guaranteed? How can the strengths of the socialist system be drawn? This issue is the subject discussed in this paper.

Obviously, the diversification of ownership structure has not made the combination of public ownership and market economy lose its central or indeed pivotal significance in the socialist market economy. In the course of deepening reforms of the economic system, if we cannot keep improving the dominant position of public ownership, fully reflect the requirements and characteristics of public ownership, utilise the superiority of the socialist system, and persist in the direction of reforming socialist market economy, it is merely an empty slogan. The shared ideal of socialism with Chinese characteristics and the lofty goals of communism will then become empty words. In this sense we can say that, whether we can realise the unity and opposition between public ownership and market economy and better integrate advantages of socialist system with strengths of market economy, will to a large extent determine the future and destiny of the socialist market economy.

\section{References}

Bruse (1989), Socialist Ownership and Political System, Huaxia Publishing House, Beijing, p. 58. Engels and Marx (2012a), Selected Works, Vol. 1, People's Publishing House, Beijing, p. 225. Engels and Marx (2012b), Selected Works, Vol. 3, People's Publishing House, Beijing, p. 364. Engels and Marx (2012c), Selected Works, Vol. 3, People's Publishing House, Beijing, p. 365. Engels and Marx (2012d), Selected Works, Vol. 3, People's Publishing House, Beijing, p. 671. Engels and Marx (2012e), Selected Works, Vol. 3, People's Publishing House, Beijing, p. 501. Engels and Marx (2012f), Selected Works, Vol. 3, People's Publishing House, Beijing, p. 363.

Guoguang, L. (2010), "Issues on socialist China's political economy", China Review of Political Economy, Vol. 1 No. 4, p. 3.

Jinping, X. (2015), "Disclosure at the 23rd collective learning meeting of the political bureau of the CPC central committee”, People's Daily, 25 November, p. 1.

Jun, H. (1982), "Theories and realities of socialist commodity currency", Teaching and Research, No. 5. Kornai (1987), Ideal and Reality, China Economic Publishing House, Beijing, pp. 61-71.

Lange (1981), Theory of Socialist Economy, China Social Science Press, Beijing, p. 24.

Marx (1975), Das Kapital, Vol. 1, People's Publishing House, Beijing, p. 95.

Marx (2004a), Das Kapital, Vol. 1, People's Publishing House, Beijing, p. 90.

Marx (2004b), Das Kapital, Vol. 1, People's Publishing House, Beijing, p. 107.

Roemer, J.E. (1994), A Future for Socialism, Harvard University Press, Boston.

Sik, O. (1989a), A Future Economic System, China Social Science Press, Beijing.

Sik, O. (1989b), For a Humane Economic Democracy, Huaxia Publishing House, Beijing.

Xiaoping, D. (1993a), Selected Works of Deng Xiaoping, Vol. 3, People's Publishing House, Beijing, p. 149.

Xiaoping, D. (1993b), Selected Works of Deng Xiaoping, Vol. 3, People's Publishing House, Beijing, p. 64.

Xuangong, W. (1998), "On the realization form of public ownership and its diversification", China Economic Studies, No. 2.

\section{Corresponding author}

Yu Zhang can be contacted at: zengbingjian2003@ruc.edu.cn

For instructions on how to order reprints of this article, please visit our website:

www.emeraldgrouppublishing.com/licensing/reprints.htm

Or contact us for further details: permissions@emeraldinsight.com 